M. Bady, Assessment of urban air quality in Assiut city-Egypt based on full scale measurements of air pollutants, pp. 997 - 1020

\title{
ASSESSMENT OF URBAN AIR QUALITY IN ASSIUT CITY-EGYPT BASED ON FULL SCALE MEASUREMENTS OF AIR POLLUTANTS
}

\author{
M. Bady \\ Department of Environmental Engineering, Egypt-Japan University of Science and Technology \\ (E-JUST), P.O. Box 179, New Borg El-Arab City, Alexandria 21934, Egypt, \\ E-mail address: mahmoud.bady@ejust.edu.eg
}

Received 13 February 2013, accepted 26 February 2013

\begin{abstract}
This study presents an assessment of the air quality in Assiut city, Egypt; in summer and in winter seasons. Full-scale measurements at four selected sites located within Assiut city are carried out using a mobile monitoring unit. The major air pollutants for which the variation of daily concentration were obtained from full-scale measurements are; sulphur dioxide $\left(\mathrm{SO}_{2}\right)$, nitrogen dioxide $\left(\mathrm{NO}_{2}\right)$, particle matter $\left(\mathrm{PM}_{10}\right)$ and carbon monoxide $(\mathrm{CO})$. The air quality analysis has been performed using the Air Quality Index (AQI) based on the four measured pollutants. The assessment criteria of air quality are classified according to the categories set by EPA as: good, moderate, unhealthful, very unhealthful and hazardous. The study results indicate that; the air pollution levels in Assiut city reached very high concentrations due to a combination of emissions from a number of different sources and adverse weather conditions. The determined AQI value exceeded the standard value of 500 in summer. It is about 2.5 times the extreme limit of 500 in almost all sites. In winter, the AQI values are below 500 in all measurement sites. However, in both seasons, the AQI values reflect hazardous air quality conditions in almost all measurement sites. The pollutant that is responsible for the worse air quality in almost cases is the suspended particulate matter $\left(\mathrm{PM}_{10}\right)$. Such results reflect that the main air pollution problem in Assiut, Egypt is the level of dust.
\end{abstract}

Keywords: Assiut Egypt Air quality, Air pollutants measurements, AQI

\section{Introduction}

In developing countries with a city like Assiut, Egypt, little attention was paid to growing air quality concerns until about a decade ago. A continuous monitoring of the urban air quality in Assiut was started in January 2000 [1] through implementation of a national strategy program for the air quality monitoring allover Egypt. The importance of air pollutants investigation in Assiut arises from the increased levels of pollutants in the ambient air. Such increase has many reasons such as the continuing expansion of industries and the increased usage of motor vehicles coupled with population growth. These sources produce a variety of pollutants in large quantities into the ambient air.

Assiut-city has several sources of industrial pollution which include two thermal power plants, oil refineries, fertilizers, bricks, cement, and food industries. Moreover, the mobile sources such as vehicles, which are now considered one of the most high pollution sources due to their polluting emissions, as most of vehicles in Assiut city, are more than 10 years old. Also, accumulation of large quantities of municipal wastes as a result of the rapid

Journal of Engineering Sciences, Assiut University, Faculty of Engineering, Vol. 41, No. 3, May, 2013, E-mail address: jes@aun.edu.eg 
M. Bady, Assessment of urban air quality in Assiut city-Egypt based on full scale measurements of air pollutants, pp. 997 - 1020

increase in population and the limited capacity of municipalities in dealing with them have led to increased open burning of such wastes. The emissions of air pollutants from the burning of wastes have exacerbated risk due to their proximity to residential areas. In addition to the anthropogenic sources, there is another natural source of pollution, which is the desert surrounding Assiut, where seasonal winds transfer dusts from the desert resulting in higher concentrations of dusts during certain times of the year (Khamasin phenomenon). The measured concentrations of dust in Egypt often ranged from 3 to 4 times the standard concentration as stated in the environmental law No. 4/1999 of Egypt [1]. It should be noted that the natural background level of dust in the atmosphere over Egypt is very high, probably higher than the standard concentration. In addition, the climate of Assiut is hot since it is located in hot arid area in Egypt. This climate is considered as one of the most important factors increasing the feeling of air pollution due to its dryness with rare rainfall. Surface winds are also inactive most times of the year. The thermo reflection phenomenon is thus repeated resulting in the trapping of pollutants in the layer near the surface of the earth.

Prior assessment of urban air quality can provide an inclusive perception of air pollution. For environmental quality assessment, a few methods, mainly index assessment, have been used by a number of researchers [2, 3, 4]. Another techniques using fuzzy synthetic evaluation has been applied to investigate the air quality [5, 6]. One simple and wellknown index is the Air Quality Index (AQI) developed by Environmental Protection Agency (EPA) [7]. The AQI converts the measured pollutant concentrations in a community's air to a number on a scale of 0 to 500. The intervals on the AQI scale relate to the potential health effects of the daily concentrations of each of the measured pollutants. Such index has been used by many researchers in the assessments of urban air quality [5].

The present study aims to assess the air quality in Assiut city in summer and in winter seasons, to estimate the effect of seasonal variation. The four major air pollutants that have been considered for such assessment are; sulphur dioxide $\left(\mathrm{SO}_{2}\right)$, nitrogen dioxide $\left(\mathrm{NO}_{2}\right)$, particle matter $\left(\mathrm{PM}_{10}\right)$ and carbon monoxide $(\mathrm{CO})$. Full-scale measurements of daily concentrations of these pollutants at four selected sites located within Assiut city are carried out using a mobile monitoring unit. The concentration of any of the air pollutants that are measured at each site is always being a sum of the interactions from the different air pollution sources in Assiut city. The air quality assessment is performed using AQI based on the four considered pollutants. The assessment criteria of air quality are classified according to the groups set by EPA [7] as: good, moderate, unhealthful, very unhealthful and hazardous. The maximum values for the current study are taken from the Egyptian air quality standards, where the long-term standard boundary value for each pollutant defined in Egypt is used.

\section{Study areas}

Assiut governorate stretches for about $120 \mathrm{~km}$ along the Nile banks. The capital of the governorate is the city of Assiut. It has a latitude of $27.33\left(27^{\circ} 19^{\prime} 60 \mathrm{~N}\right)$ and a longitude of $30.83\left(30^{\circ} 49^{\prime} 60 \mathrm{E}\right)$. Such location is situated 90 kilometers north east $\left(66^{\circ}\right)$ of the

Journal of Engineering Sciences, Assiut University, Faculty of Engineering, Vol. 41, No. 3, May, 2013, E-mail address: jes@aun.edu.eg 
M. Bady, Assessment of urban air quality in Assiut city-Egypt based on full scale measurements of air pollutants, pp. $997-1020$

approximate center of Egypt and 375 kilometers south $\left(188^{\circ}\right)$ of the capital Cairo. Figure 1 shows a map of Egypt and the location of Assiut governorate.

Assiut governorate has an area of $25,926 \mathrm{~km}^{2}$ (which represents $2.6 \%$ of the total area of Egypt) and a population of over 4.0 million with an average density of 119.6 people per $\mathrm{km}^{2}$ of the inhabited area. The locations of the four measurement sites in Assiut are indicted on a map of Assiut city, as shown in Fig.2. These sites are: (1) El-Arbein, (2) Assiut University hospital, (3) Old campus of Assiut University, and (4) Nazlet Abdellah.

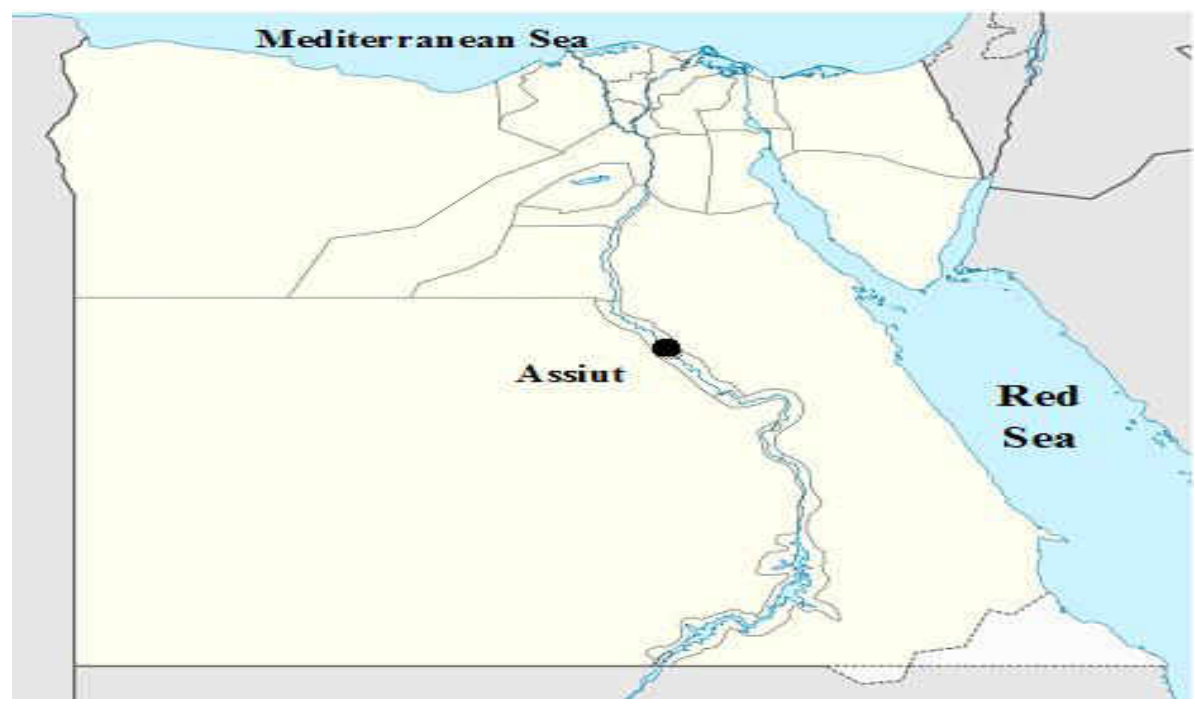

Fig. 1. Egypt map shows the location of the Assiut city.

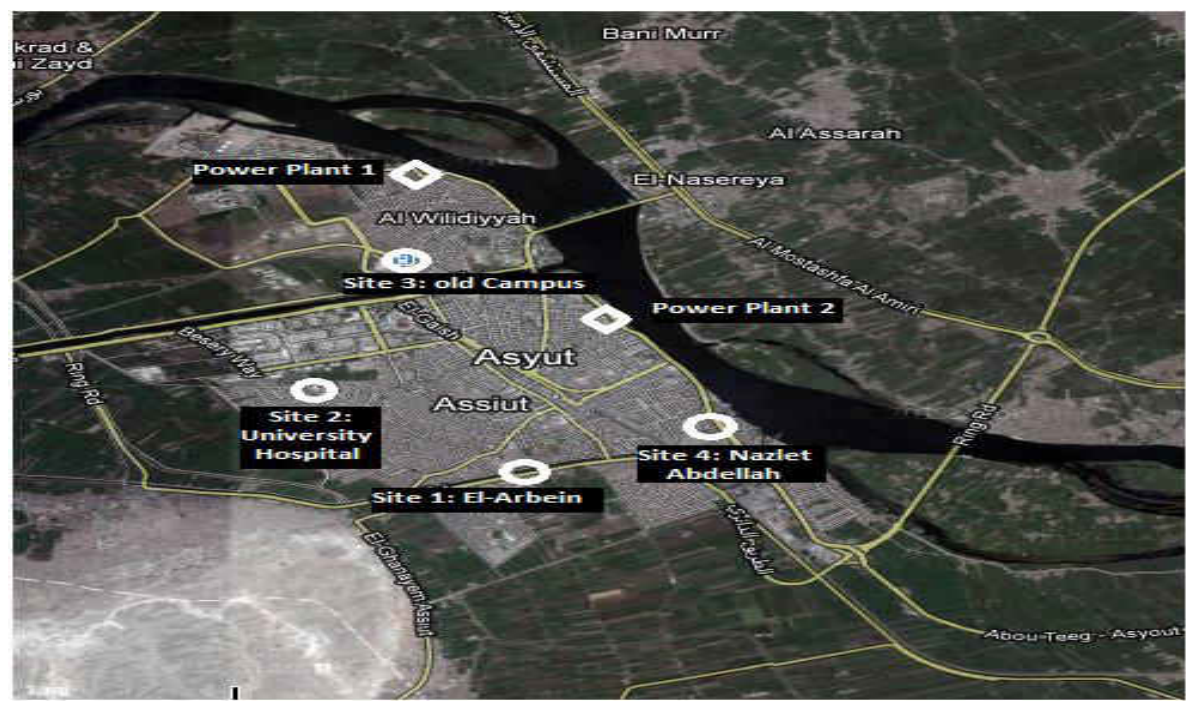

Fig. 2. Map of Assiut city shows the four measurement sites.

Journal of Engineering Sciences, Assiut University, Faculty of Engineering, Vol. 41, No. 3, May, 2013,E-mail address: jes@aun.edu.eg 
1000

M. Bady, Assessment of urban air quality in Assiut city-Egypt based on full scale measurements of air pollutants, pp. 997 - 1020

Each of the considered sites has its own characteristics which gave us the motivation to investigate its air quality conditions. The first site is located in the southern part of Assiut city, which is called El-Arbein region. It is a high-density residential area. The traffic density, together with the people activities are the main sources of air pollution in such area. The second site is the Assiut University hospital. It was selected to investigate the air quality condition since the hospital is located on the side of crowded traffic road and close to a high way. Such road is the source of different vehicular emissions in such area. The third site is chosen near the old campus of Assiut University, which is located very close to one of the most crowded areas in Assiut city. In that area, a very important bridge which connects the two sides of Assiut city over the Nile River exists. The vehicular emissions due to the traffic density through the sides of the bridge are important to be investigated. The last site is located at Nazlet Abdellah region. The emissions of one of Assiut thermal power plants are carried to this area by the blowing wind (downwind area of the power plant). Moreover, this area is near from the west mountain of Assiut, which means that the dust level in this area is expected to be high. Table 1 shows the measurements sites in Assiut city together with the dates of measurements in summer 2011 and in winter 2010.

Table 1.

The four sites in Assiut city and dates of measurements

\begin{tabular}{lcc}
\hline \hline \multirow{2}{*}{ ID Measurement site } & \multicolumn{2}{c}{ Measurement date } \\
\cline { 2 - 3 } & Summer 2011 & Winter 2010 \\
\hline 1. El-Arbein & $20 / 6 / 2011$ & $10 / 12 / 2010$ \\
2. Assiut hospital & $10 / 6 / 2011$ & $30 / 11 / 2010$ \\
3. Assiut University old-campus & $14 / 6 / 2011$ & $7 / 12 / 2010$ \\
4. Nazlet Abdellah & $17 / 6 / 2011$ & $14 / 12 / 2010$ \\
\hline
\end{tabular}

The long and short term boundary values of each pollutant are determined based on Egypt environmental law No. 4/1994 [1]. These values are given in Table 2. The long-term boundary value gives the maximum allowable annual arithmetic mean and short-term boundary value gives the maximum daily arithmetic mean. In addition, Table 2 shows the EPA standard values as reference standards.

Table 2.

Ambient air quality standards [1, 7]

\begin{tabular}{lcc}
\hline \hline \multicolumn{1}{c}{ Pollutant } & $\begin{array}{c}\text { Egyptian Standard } \\
\left(\mu \mathrm{g} / \mathrm{m}^{3}\right)\end{array}$ & $\begin{array}{c}\text { EPA Standard } \\
\left(\mu \mathrm{g} / \mathrm{m}^{3}\right)\end{array}$ \\
\hline Sulfur Dioxide $\left(\mathrm{SO}_{2}\right)$ & $150(24 \mathrm{~h}) 60($ annual) & $365(24 \mathrm{~h}) 80($ annual $)$ \\
Carbon Monoxide $(\mathrm{CO})^{(1)}$ & $30,000(1 \mathrm{~h}) 10,000(8 \mathrm{~h})$ & $40,000(1 \mathrm{~h}) 10,000(8 \mathrm{~h})$ \\
Nitrogen Dioxide $\left(\mathrm{NO}_{2}\right)^{(2)}$ & $400(1 \mathrm{~h}) 150(24 \mathrm{~h})$ & $100($ annual) $150(24 \mathrm{~h})$ \\
Particulate Matter $(\mathrm{PM})$ & $150(24 \mathrm{~h}) 70($ annual $)$ & $50($ annual $)$ \\
\hline \hline
\end{tabular}

Journal of Engineering Sciences, Assiut University, Faculty of Engineering, Vol. 41, No. 3, May, 2013,E-mail address: jes@aun.edu.eg 
M. Bady, Assessment of urban air quality in Assiut city-Egypt based on full scale measurements of air pollutants, pp. 997 - 1020

${ }^{(1)}$ No limits for the exposure along a period of 24 hours or a year are specified in both the Egyptian and EPA standards.

(2) No annual limit for the concentration of $\mathrm{NO}_{2}$ is available in the Egyptian standard, while there is no short term value available in EPA standard.

\section{Major air pollutants monitored in the present study}

\subsection{Sulphur dioxide $\left(\mathrm{SO}_{2}\right)$}

Sulfur dioxide is primarily generated as a result of sulfur residues oxidation in liquid petroleum fuels during combustion process in either stationary sources as energy generation stations and factories or mobile sources as vehicles, especially those operated with diesel fuel; and the use of diesel fuel in power plants and brick factories.

\subsection{Nitrogen dioxide $\left(\mathrm{NO}_{2}\right)$}

Nitrogen dioxide is one of a number of important nitrogen oxides present in the atmosphere. Nitric oxide and nitrogen dioxide (together termed $\mathrm{NO}_{\mathrm{x}}$ ) are the most abundant man-made oxides of nitrogen in urban areas; which are mainly formed in high temperature combustion processes. Nitrogen emissions in Assiut city originate from motor vehicles, with most of the remainder arising from thermal power stations and other industrial sources. Since emissions of power stations and industrial facilities are usually from chimneys, motor vehicles represent the nearest source to ground for $\mathrm{NO}_{2}$ emission and therefore increase the ground level concentrations in urban areas.

\subsection{Carbon monoxide ( $\mathrm{CO})$}

Carbon monoxide is emitted from cars exhaust gases, coal or wood combustion. It is classified as one of the most dangerous types of air pollutants and the most toxic to humans and animals. This is due to its combination with hemoglobin forming Carboxyhemoglobin which prevents oxygen from combining with hemoglobin and thus deprives body from accessing oxygen that consequently causes internal suffocation.

\subsection{Particulate matter $\left(P M_{10}\right)$}

Suspended particles in the atmosphere are considered as the major pollution problem in Egypt, especially in Assiut city due to the multiplicity and various sources of air pollution. Dry climate, dessert areas around the city and windy conditions normally generate the relatively large particles which are found as total suspended particulates (TSP) or as dust fall. The $\mathrm{PM}_{10}$ are mainly generated from industrial processes, and thus may carry other hazardous pollutants. High concentrations of $\mathrm{PM}_{10}$ are also generated by traffic, especially diesel engine driven vehicles, in the streets.

Journal of Engineering Sciences, Assiut University, Faculty of Engineering, Vol. 41, No. 3, May, 2013, E-mail address: jes@aun.edu.eg 
M. Bady, Assessment of urban air quality in Assiut city-Egypt based on full scale measurements of air pollutants, pp. 997 - 1020

\section{Wind data measurements}

Wind speed measurements were carried out by the governmental meteorological station which is located in Assiut University campus. The data were measured for a period of five years starting from 2006 to 2010 at the standard height of $10 \mathrm{~m}$ and averaged over one hour. Sixteen wind directions are considered, where the incident wind direction is varied from $\mathrm{N}$ to $\mathrm{NNW}$ in a clockwise rotation with a step of $22.5^{\circ}$. Figure 3 shows the wind rose of Assiut city.

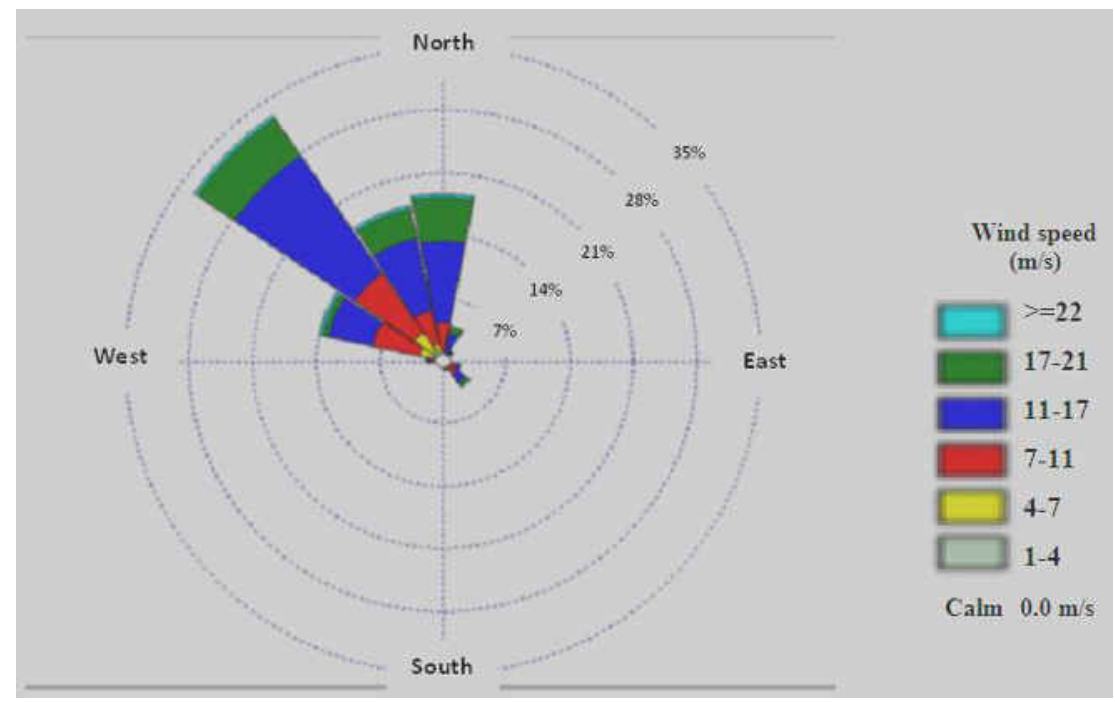

Fig. 3. Wind rose of Assiut based on mean wind speed (averaged over 1 hour)

\section{Mobile monitoring unit}

\subsection{Unit description}

Monitoring of air quality in the present study was performed using the mobile monitoring unit of the environmental affairs agency, Assiut branch. The unit is equipped with all instrumentations needed for data sampling, manipulation and acquisition required for monitoring of several gaseous pollutants, particle matters and meteorological conditions. Those instrumentations are installed in an air conditioned cabinet $(4.3 \times 2.3 \times 2.3$ $\mathrm{m}^{3}$ ) of a medium size truck. The mobile unit is shown in Fig. 3 [9]. It has a 8.2 liter 8cylinder, V- shaped, 159 HP diesel engine. The unit cabinet is divided into two compartments; one for instrumentation and a small rear one $(0.75 \mathrm{~m}$ wide) used as a store and as transition zone to the instrumentation compartment. The instrumentation compartment contains air pollution monitoring instruments, particulate high volume sampler controller, meteorological data recorders and translators, data acquisition and

Journal of Engineering Sciences, Assiut University, Faculty of Engineering, Vol. 41, No. 3, May, 2013, E-mail address: jes@aun.edu.eg 
M. Bady, Assessment of urban air quality in Assiut city-Egypt based on full scale measurements of air pollutants, pp. 997 - 1020

computer systems. All instrumentations inside the cabinets are powered either from electricity mains or from an AC generator integrated with its own diesel engine and which can be trailed by the truck.

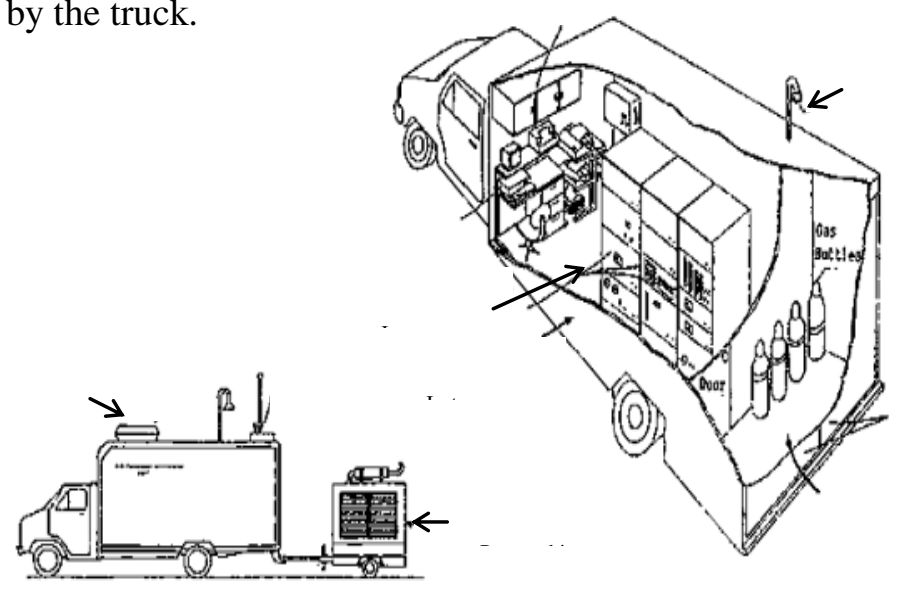

Fig. 4. Air pollution measuring unit.

\subsection{Principle of measurement}

\subsubsection{Detection of $\mathrm{SO} 2$}

The capture of $\mathrm{SO}_{2}$ is carried out by a means of pulsed fluorescent analyzer. As described in [8], the operating principle of such instrument is based on measuring the emitted fluorescence of $\mathrm{SO}_{2}$ produced by the gas's absorption of $\mathrm{UV}$ radiation. Pulsating UV light is focused through a narrow band-pass filter mirror allowing only specific light wavelengths to pass into the fluorescent chamber. $\mathrm{SO}_{2}$ absorbs light in this region without any quenching by air or most other molecules found in polluted air. The $\mathrm{SO}_{2}$ molecules are excited by UV light and emit a characteristic decay radiation [8].

\subsubsection{Detection of $P M_{10}$}

For measuring $\mathrm{PM}_{10}$ concentrations, the amount of radiation a sample absorbs is measured when exposed to a radioactive source. Low energy beta rays are absorbed by collision with electrons, whose number is proportional to density. Absorption is thus a function of the mass of the irradiated material, independently of its physicochemical nature [8].

\subsubsection{Detection of $C O$}

The capture of $\mathrm{CO}$ is carried out by means of Fourier Transform Infrared (FTIR) absorption spectroscopy. As described in [8], the operating principle of absorption spectroscopy refers to spectroscopic techniques that measure the absorption of radiation, as a function of frequency or wavelength, due to its interaction with a sample. The sample

Journal of Engineering Sciences, Assiut University, Faculty of Engineering, Vol. 41, No. 3, May, 2013, E-mail address: jes@aun.edu.eg 
1004

M. Bady, Assessment of urban air quality in Assiut city-Egypt based on full scale measurements of air pollutants, pp. $997-1020$

absorbs energy, i.e., photons, from the radiating field. The intensity of the absorption varies as a function of frequency, and this variation is the absorption spectrum [8].

\subsubsection{Detection of $\mathrm{NO}_{x}$}

Gas molecules can absorb radiation if the radiation can electronically excite or change the vibrational or rotational energy of the molecule. By measuring the spectrum of radiation before and after the trace gas absorption, it is possible to calculate a concentration using Beer's Law. Accordingly, measurements of $\mathrm{NO}$ and $\mathrm{NO}_{2}$ are performed using Differential Optical Absorption Spectroscopy (DOAS), which measures the spectroscopic molecular absorption of NOx over an open atmospheric path. Nitrogen oxides can be detected in the UV/visible spectral region with higher sensitivities than in the infrared due to greater absorption coefficients [8].

\section{Air quality index}

The Air Quality Index (AQI) is an index developed by EPA [7] to determine whether air quality levels in a particular location are good, moderate, unhealthful, or worse. The AQI is used as an information tool to advise the public. It is often presented along with the weather report in local newspapers.

The AQI is determined based on measurements of five criteria air pollutants; groundlevel ozone $\left(\mathrm{O}_{3}\right)$, particulate matter, sulfur dioxide, carbon monoxide and nitrogen dioxide. In the present study, the measured ozone concentrations were very low. Accordingly, in this study the determination of AQI is carried out based on the rest four air pollutants.

The AQI represents the measured pollutant concentrations in a community's air when converted as described below to a number on a scale of 0 to 500. The intervals on the AQI scale relate to the potential health effects of the daily concentrations of each of these five pollutants. The most important number on this scale is 100, since this number corresponds to the National Ambient Air Quality Standard established by EPA [7]. An AQI level in excess of 100 means that a pollutant is in the unhealthful range on a given day; an AQI level at or below 100 means that a pollutant reading is in the satisfactory range. The air quality index categories as described in [4] are shown in Table 3.

Table 3.

Air quality index categories [4]

\begin{tabular}{llc}
\hline \hline AQI value & Description & Symbol \\
\hline $0-50$ & Good & $\mathrm{A}$ \\
$51-100$ & Moderate & $\mathrm{B}$ \\
$101-200$ & Unhealthful & $\mathrm{C}$ \\
$201-300$ & Very Unhealthful & $\mathrm{D}$ \\
$300+$ & Hazardous & $\mathrm{E}$ \\
\hline \hline
\end{tabular}

Journal of Engineering Sciences, Assiut University, Faculty of Engineering, Vol. 41, No. 3, May, 2013,E-mail address: jes@aun.edu.eg 
M. Bady, Assessment of urban air quality in Assiut city-Egypt based on full scale measurements of air pollutants, pp. $997-1020$

To convert a pollutant concentration into AQI, the following formula is used [5]:

$$
I_{i}=\frac{c_{i}}{S_{i}} \times 500
$$

where

$I_{i}$ is the air quality index of pollutant $i$,

$c_{i}$ is the pollutant $i$ concentration $\left(\mu \mathrm{g} / \mathrm{m}^{3}\right)$,

$S_{i}$ is pollutant $i$ standard $\left(\mu \mathrm{g} / \mathrm{m}^{3}\right)$.

The assessment criteria of air quality are classified according to the groups set by EPA [7] as: good, moderate, unhealthful, or worse. The maximum values for the current study were taken from the Egyptian air quality standards presented in Table 2. The overall air quality index is calculated as the maximum of the four sub-indices as follows: $A Q I=\operatorname{Max}\left(I_{\mathrm{SO}_{2}}, I_{\mathrm{NO}_{2}}, I_{\mathrm{CO}}, I_{\mathrm{PM}}\right)$

\section{Results and discussion}

\subsection{Assessment of Air Quality based on Daily Concentrations}

The time series concentrations of the four considered pollutants in the four measurement sites in Assiut city together with the measured wind velocity are presented in Figs. 5 to 8 . The pollutant concentration measurements were carried out in the four selected sites for 24 hours in winter 2010 and in summer 2011. The wind velocity measurements were carried out for $24 \mathrm{hrs}$ in summer 2011 from 12:00 AM to 12:00 AM. In winter 2010, the measurements were carried out for $18 \mathrm{hrs}$ from 2:00 AM to 8:00 PM. In each figure, a comparison between pollutant time series concentration in winter and in summer is presented, and the Egyptian standard short-term value of each pollutant is illustrated for evaluating the air quality over the 24 hours of measurements.

In Fig. 5, the measured pollutant concentrations in El- Arbein site are presented. The figure shows that; $\mathrm{SO}_{2}, \mathrm{NO}_{2}$ and $\mathrm{CO}$ concentrations are fluctuating along the $24 \mathrm{hrs}$, either in winter or in summer. However, the average concentrations of theses pollutants in both seasons are lower than their Egyptian standard concentrations throughout the measurement period. The $\mathrm{PM}_{10}$ concentration exceeds the standard value during summer season, while in winter; its concentration is lower than the limit for the measurement period. Concerning the concentrations of $\mathrm{CO}$ and $\mathrm{NO}_{2}$, the measurements show that their concentrations are within the permissible concentrations in winter and in summer. Both the concentrations of $\mathrm{CO}$ and $\mathrm{NO}_{2}$ have peaks in the time from 6:00 PM to 11:00 PM in winter and in summer since those periods are characterized by high traffic density.

The $\mathrm{PM}_{10}$ concentration is fluctuating significantly along the $24 \mathrm{hrs}$. In addition, the $\mathrm{PM}_{10}$ average concentration over the period of measurements in summer is almost twice that of winter. This can be attributed to the seasonal variations in the prevailing wind conditions in Assiut city. As indicated in Fig. 5; the average wind speed has the lowest value in winter especially in December $(5.2 \mathrm{~m} / \mathrm{s})$ and the maximum value in summer especially in June (7.3

Journal of Engineering Sciences, Assiut University, Faculty of Engineering, Vol. 41, No. 3, May, 2013, E-mail address: jes@aun.edu.eg 
1006

M. Bady, Assessment of urban air quality in Assiut city-Egypt based on full scale measurements of air pollutants, pp. 997 - 1020

$\mathrm{m} / \mathrm{s}$ ). Consequently, the incident wind carries the dust from the surrounding mountains to the city urban area.

The ventilation effectiveness of the prevailing wind in the site prevents the accumulation of such pollutants within the considered domain and mitigates them. An important point to be observed from the figure is that; the high concentration values of $\mathrm{CO}$ and $\mathrm{NO}_{2}$ are from 6:00 PM to 12:00 AM. Such increase is attributed to the traffic jam that occurs in the city during this period together with the low wind velocity in the same period of time as shown in the last subplot of Fig. 5.

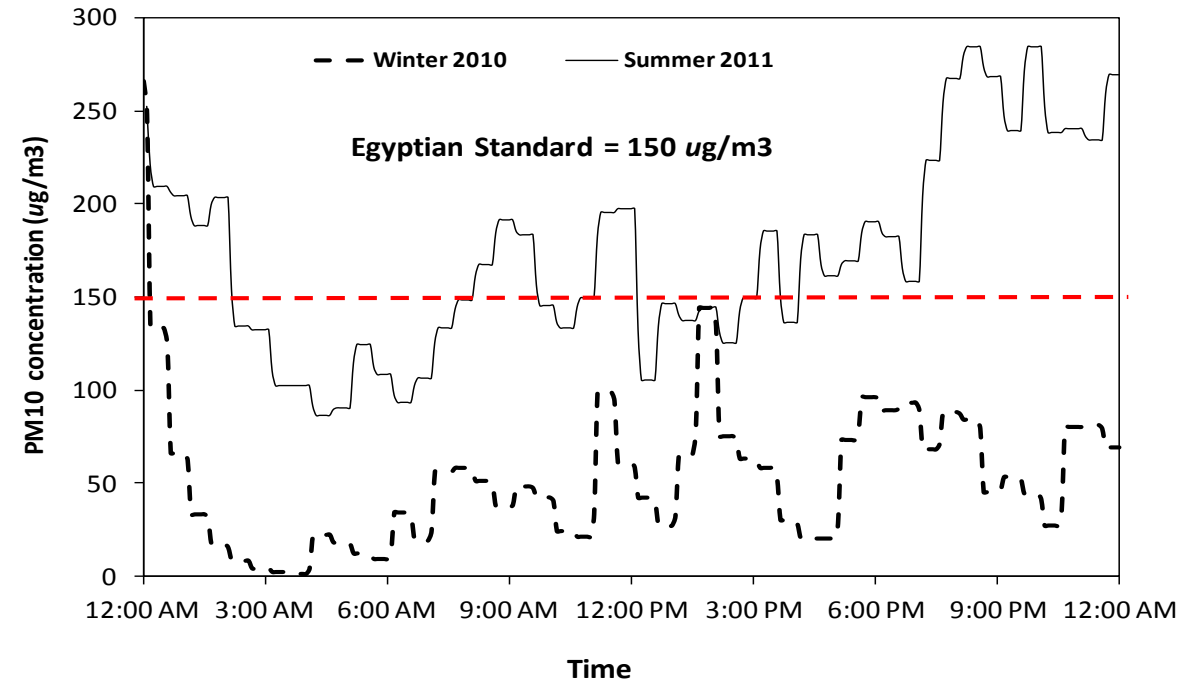

(a)

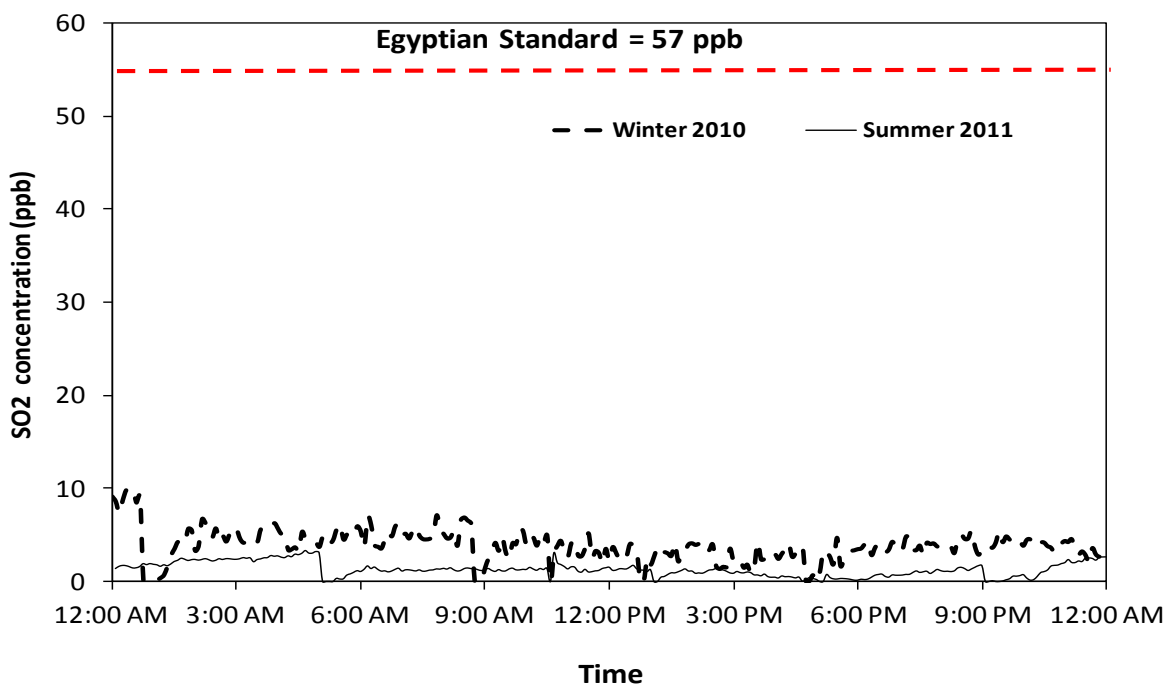

(b)

Journal of Engineering Sciences, Assiut University, Faculty of Engineering, Vol. 41, No. 3, May, 2013,E-mail address: jes@aun.edu.eg 
M. Bady, Assessment of urban air quality in Assiut city-Egypt based on full scale measurements of air pollutants, pp. 997 - 1020

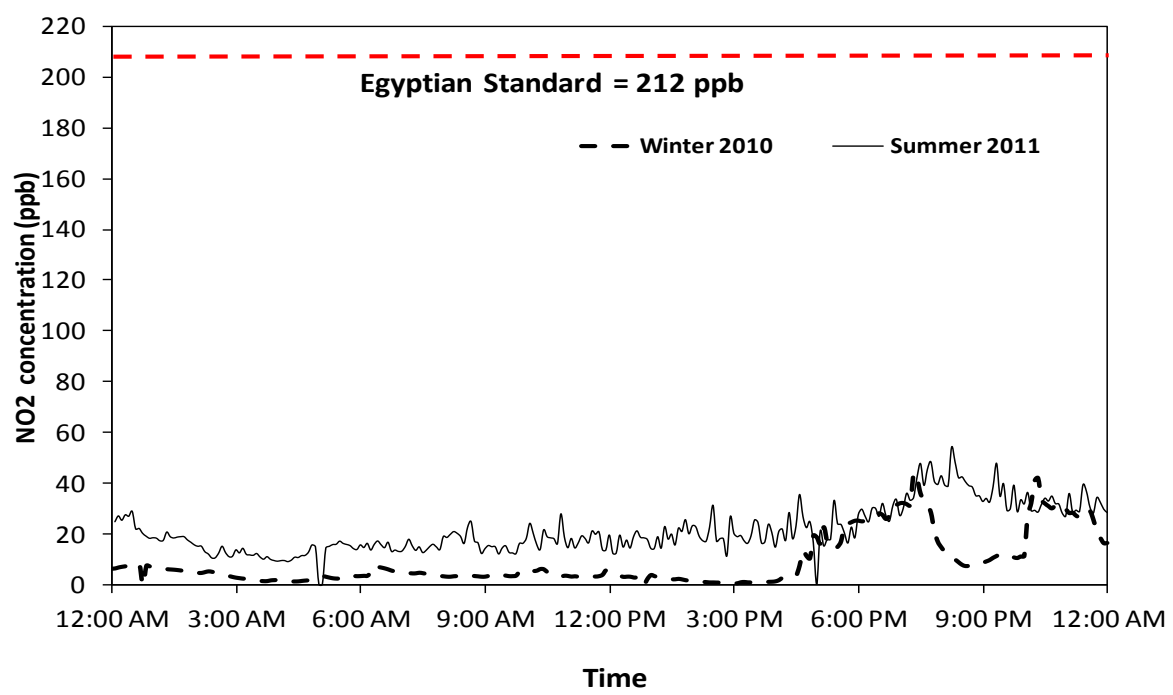

(c)

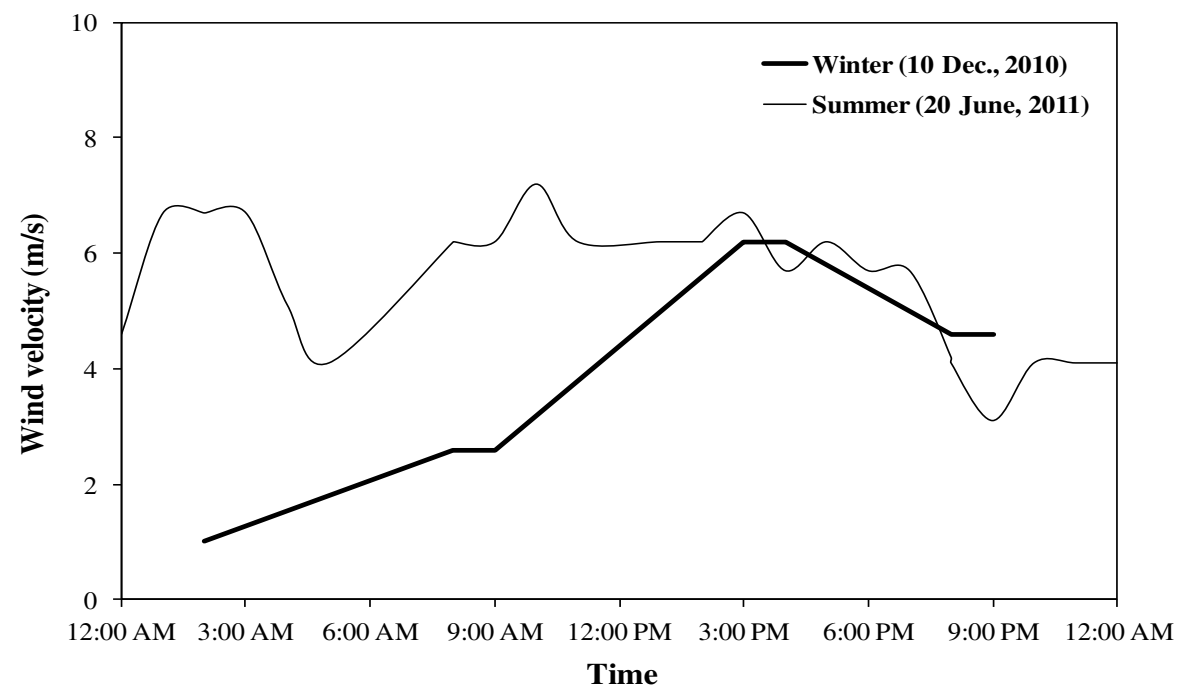

(d)

Journal of Engineering Sciences, Assiut University, Faculty of Engineering, Vol. 41, No. 3, May, 2013, E-mail address: jes@aun.edu.eg 
M. Bady, Assessment of urban air quality in Assiut city-Egypt based on full scale measurements of air pollutants, pp. $997-1020$

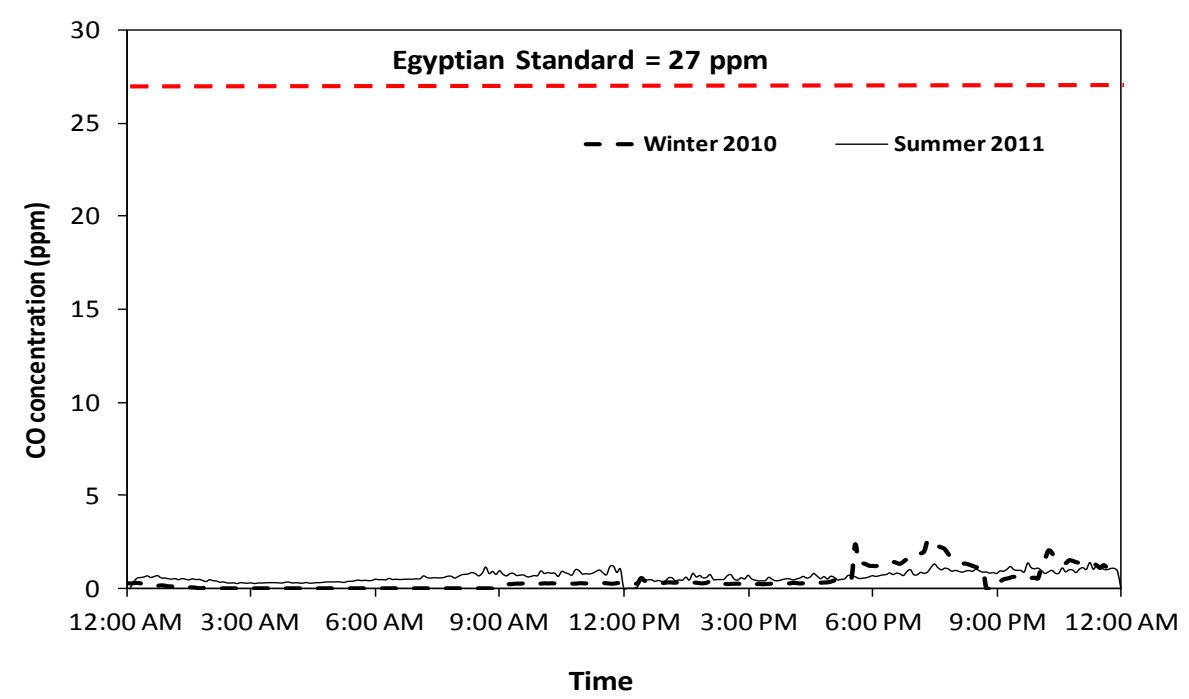

(e)

Fig. 5. The measured wind velocity and pollutants concentration in El- Arbein region

The pollutants concentration time series in the second measurement site, which is located within Assiut University hospital campus, is shown in Fig. 6. Similar to the first site, the $\mathrm{PM}_{10}$ concentration exceeds the permissible limit in summer along the whole measurement period. The concentration of $\mathrm{SO}_{2}$ does not exceed the permissible limit, either in winter or in summer. This can be referred to the fact that; the site is far from Assiut thermal power plants emissions.

The concentrations time series of $\mathrm{CO}$ and $\mathrm{NO}_{2}$ show high fluctuations with time. The $\mathrm{NO}_{2}$ concentration exceeds the Egyptian standard during three periods along the day of measurements in winter, while in summer the concentration is lower than the allowable limit. Moreover, in the winter, cold weather along with the low wind velocity particularly in the morning and afternoon periods help in trapping the pollutants in the measured site.

Figure 7 shows the wind velocity and pollutants concentration in the site No. 3, which is located near the old-campus of Assiut University. There is significantly more fluctuation intensity in the concentrations of $\mathrm{SO}_{2}$ and $\mathrm{PM}_{10}$ compared with $\mathrm{NO}_{2}$ and $\mathrm{CO}$. In winter, the $\mathrm{PM}_{10}$ concentration is very close to maximum level (standard limit stipulated in law No. 4/1994), for almost the second half of the day. In summer, there are two peaks along the 24 hours in which the $\mathrm{PM}_{10}$ concentration exceeds the standard limit. It depends on the conditions of the incident wind.

The measured levels of $\mathrm{CO}$ and $\mathrm{NO}_{2}$ are lower than the permissible limits of such pollutants, along the $24 \mathrm{hrs}$ both in winter and in summer. This can be attributed to the high ventilation performance of the incident wind within the domain of this site as it is located in the north-east border of the city.

Journal of Engineering Sciences, Assiut University, Faculty of Engineering, Vol. 41, No. 3, May, 2013, E-mail address: jes@aun.edu.eg 
M. Bady, Assessment of urban air quality in Assiut city-Egypt based on full scale measurements of air pollutants, pp. 997 - 1020

The pollutants concentration time series in the site of Nazlet Abdellah is shown in Fig. 8 . The figure shows that; the air quality conditions in this site are worth than the other three sites, especially in summer. The level of air pollution is increased due to the presence of Assiut thermal power plant and the vehicular emissions from the high way traffic road that passes in this area. Moreover, this area is near from the west mountain of Assiut, which increases the dust level compared to the other locations in the city.

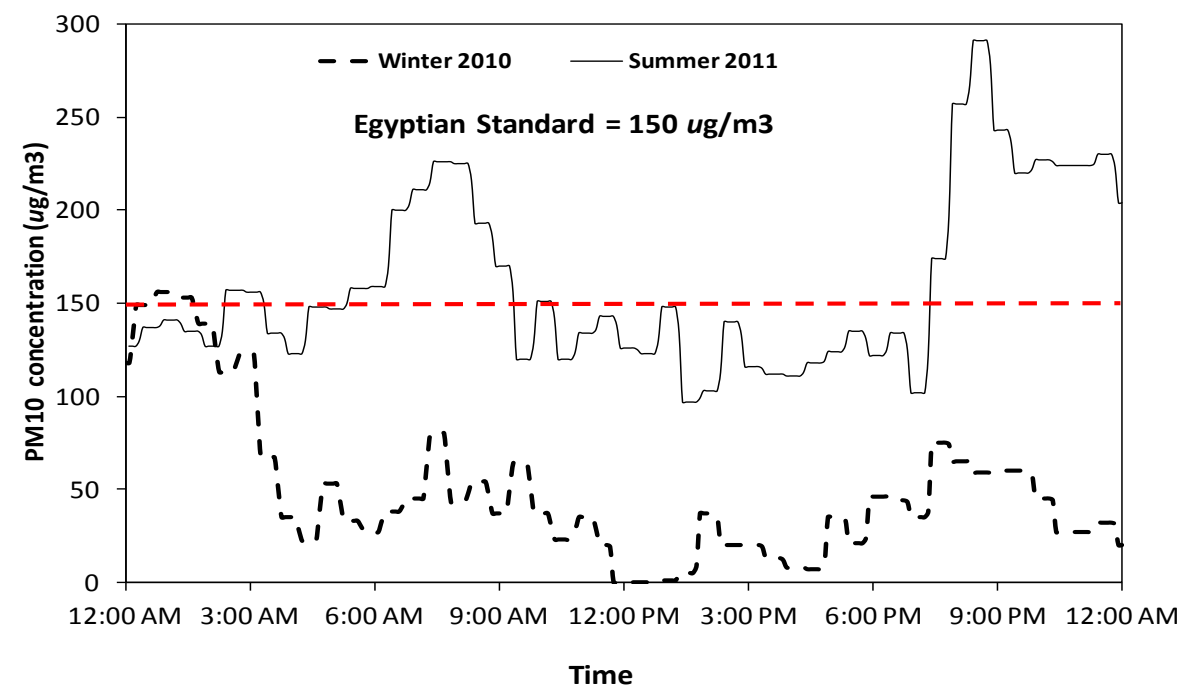

(a)

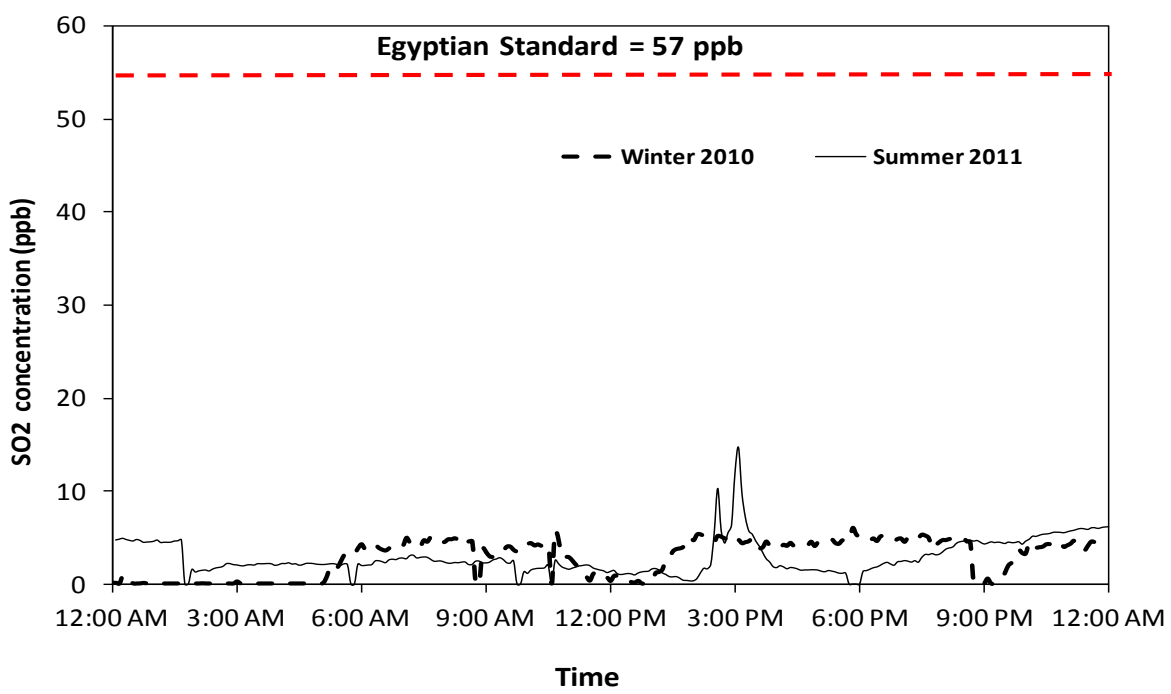

(b)

Journal of Engineering Sciences, Assiut University, Faculty of Engineering, Vol. 41, No. 3, May, 2013,E-mail address: jes@aun.edu.eg 
M. Bady, Assessment of urban air quality in Assiut city-Egypt based on full scale measurements of air pollutants, pp. 997 - 1020

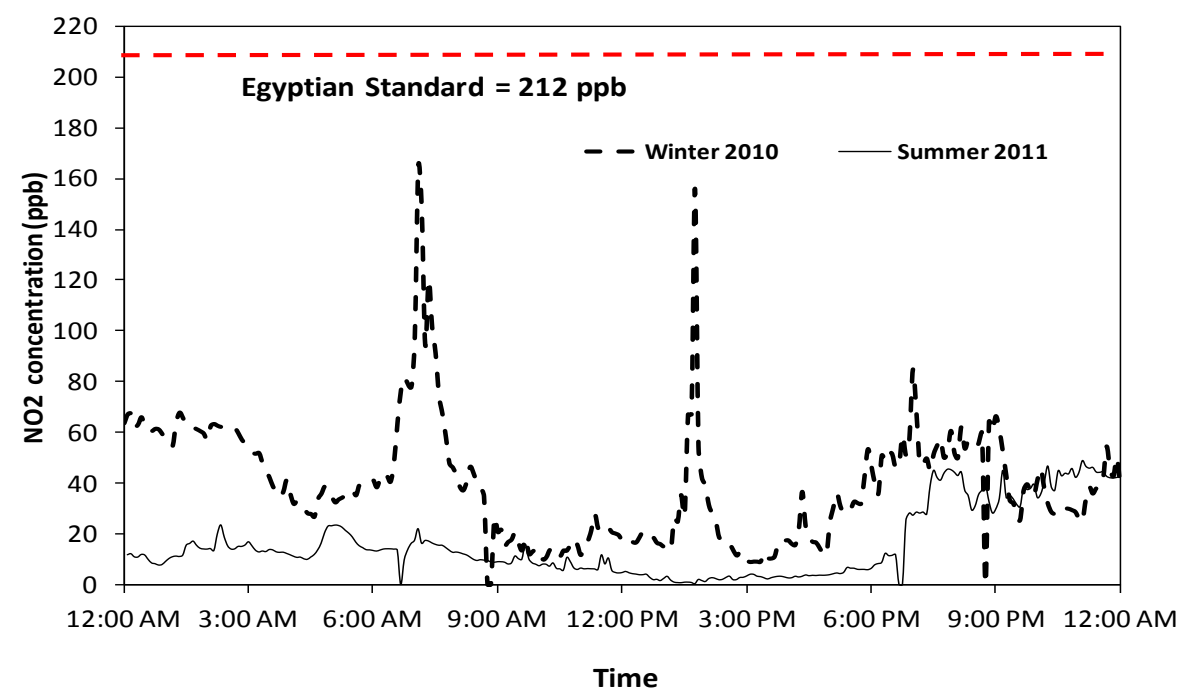

(c)

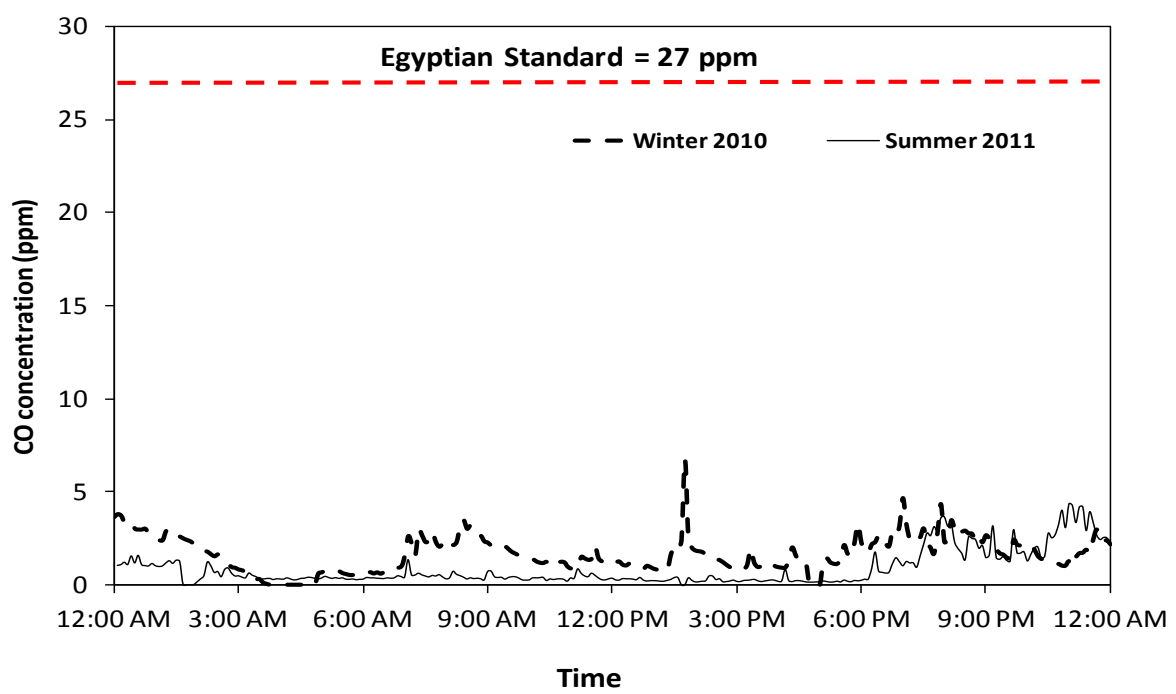

(d)

Journal of Engineering Sciences, Assiut University, Faculty of Engineering, Vol. 41, No. 3, May, 2013,E-mail address: jes@aun.edu.eg 
M. Bady, Assessment of urban air quality in Assiut city-Egypt based on full scale measurements of air pollutants, pp. 997 - 1020

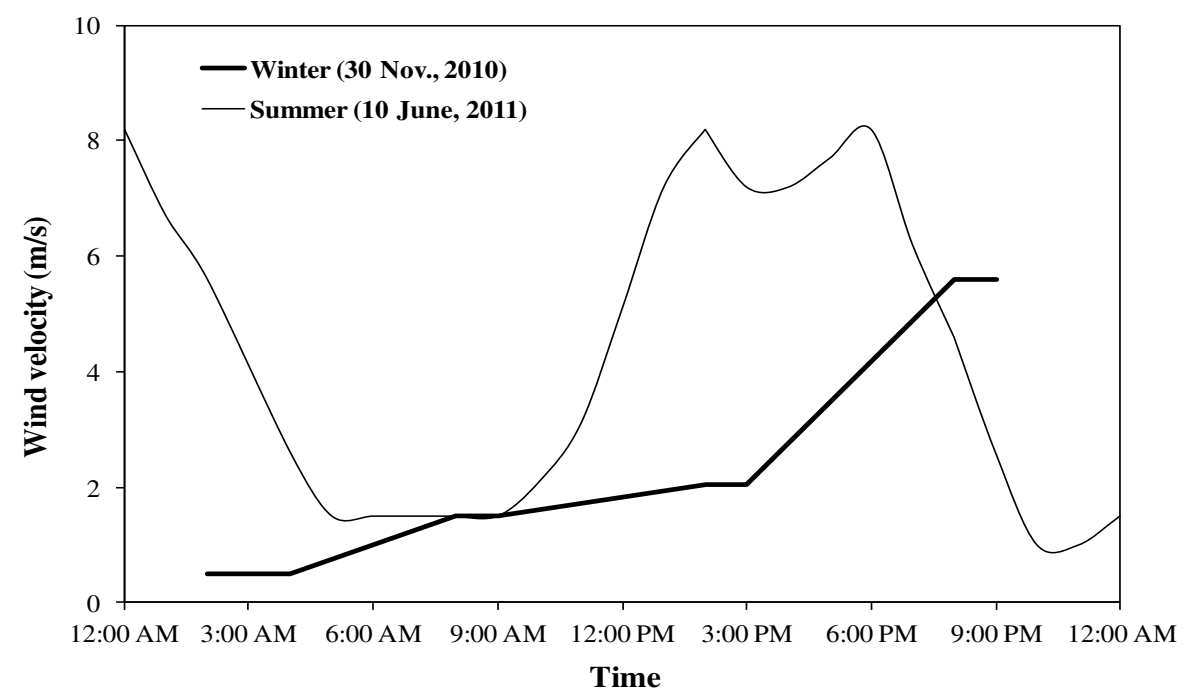

(e)

Fig. 6. The measured wind speed and pollutants concentration in the site of Assiut University hospital.

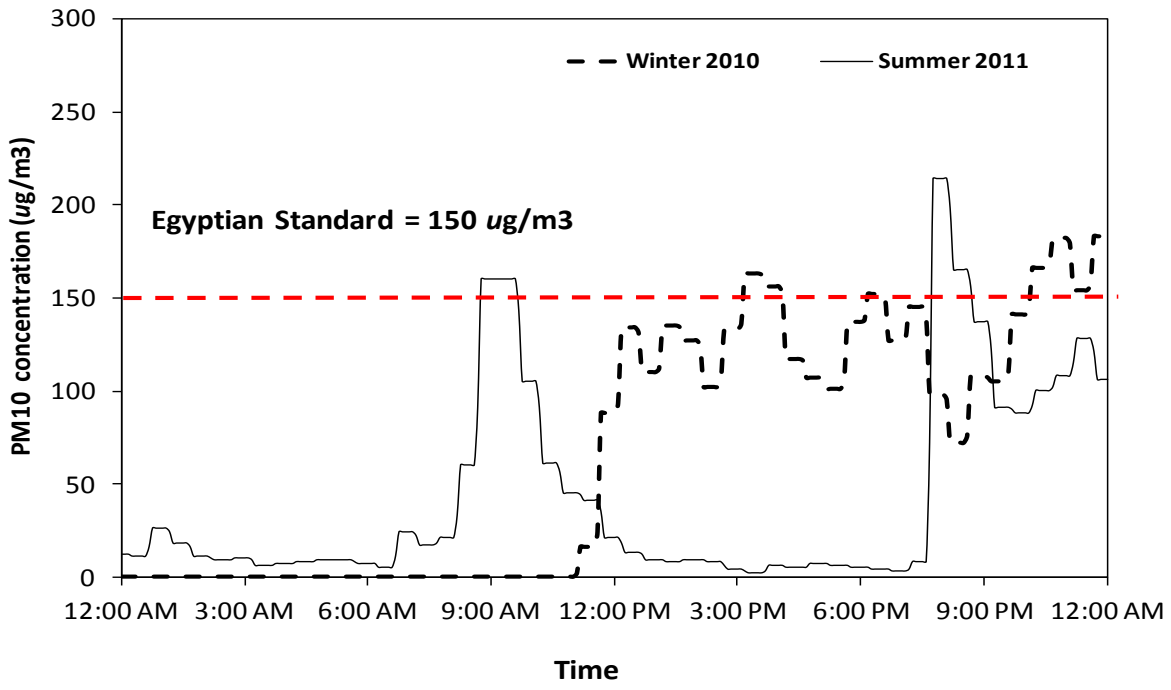

(a)

Journal of Engineering Sciences, Assiut University, Faculty of Engineering, Vol. 41, No. 3, May, 2013,E-mail address: jes@aun.edu.eg 
1012

M. Bady, Assessment of urban air quality in Assiut city-Egypt based on full scale measurements of air pollutants, pp. 997 - 1020

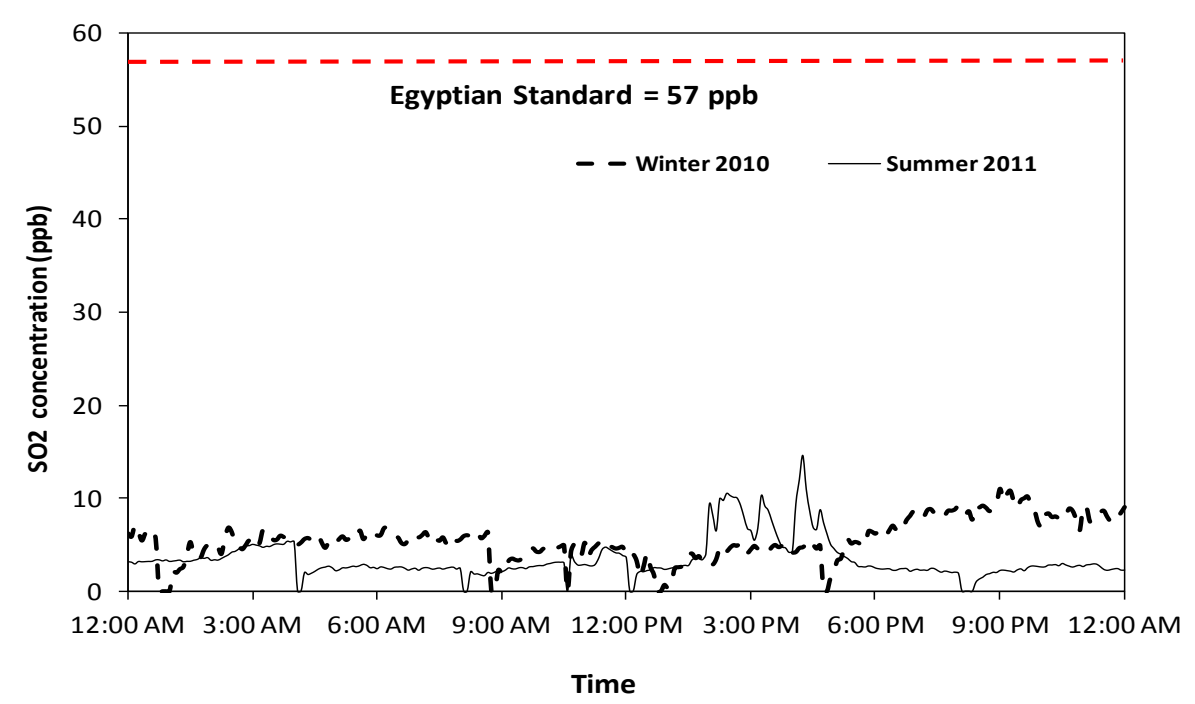

(b)

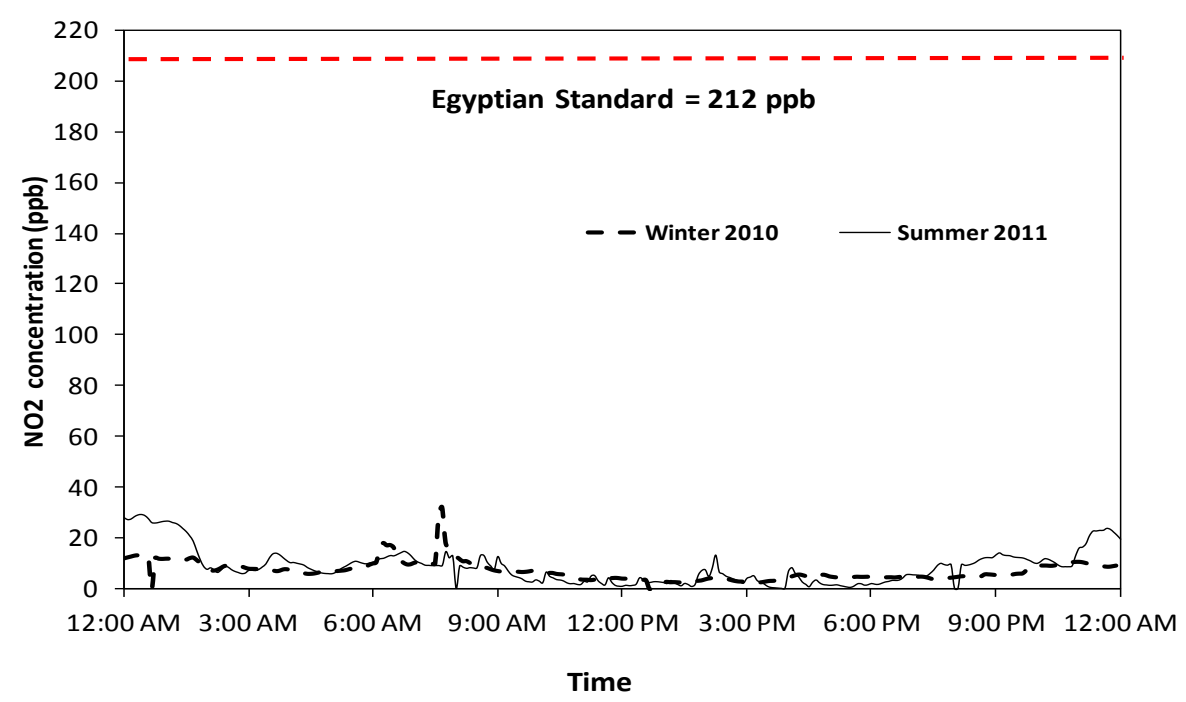

(c)

Journal of Engineering Sciences, Assiut University, Faculty of Engineering, Vol. 41, No. 3, May, 2013,E-mail address: jes@aun.edu.eg 
M. Bady, Assessment of urban air quality in Assiut city-Egypt based on full scale measurements of air pollutants, pp. 997 - 1020

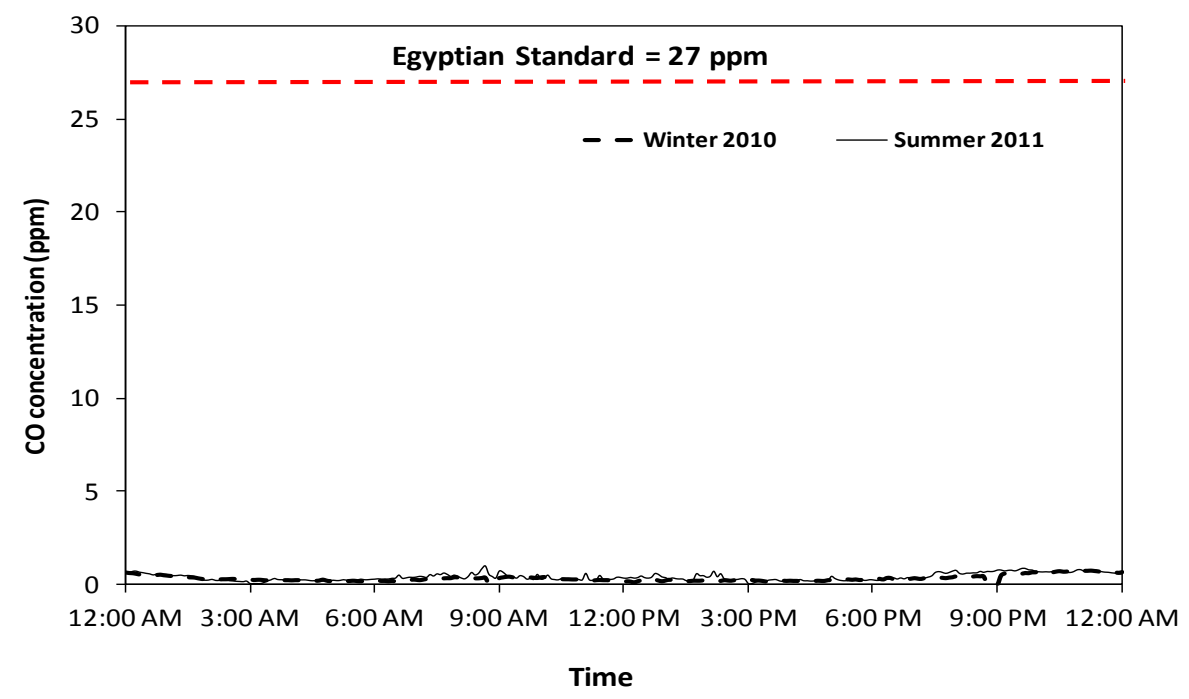

(d)

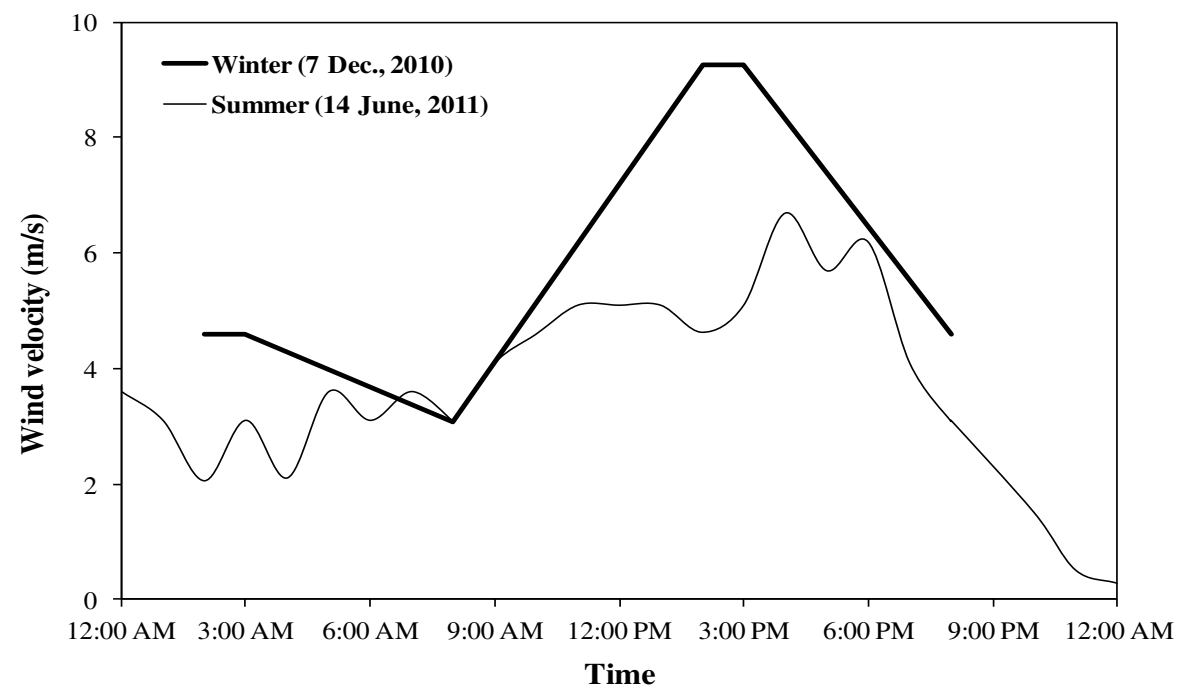

(e)

Fig. 7. The measured wind velocity and pollutants concentration in the site of Assiut University old-campus.

Journal of Engineering Sciences, Assiut University, Faculty of Engineering, Vol. 41, No. 3, May, 2013,E-mail address: jes@aun.edu.eg 
1014

M. Bady, Assessment of urban air quality in Assiut city-Egypt based on full scale measurements of air pollutants, pp. 997 - 1020

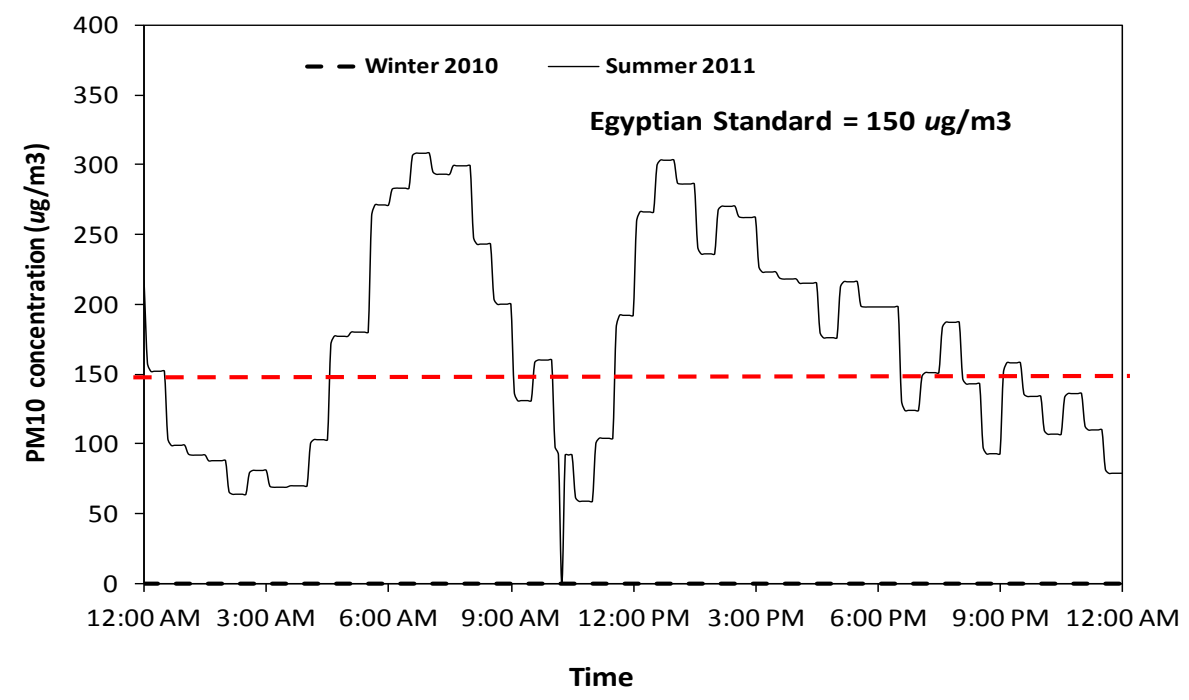

(a)

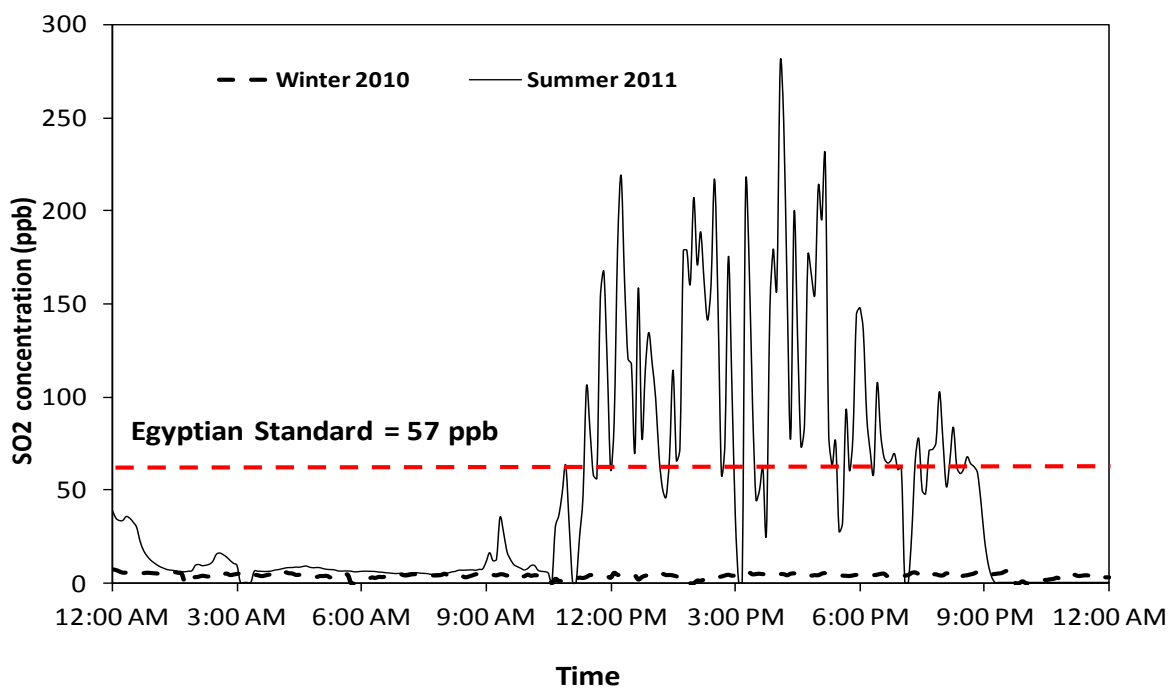

(b)

Journal of Engineering Sciences, Assiut University, Faculty of Engineering, Vol. 41, No. 3, May, 2013,E-mail address: jes@aun.edu.eg 
M. Bady, Assessment of urban air quality in Assiut city-Egypt based on full scale measurements of air pollutants, pp. 997 - 1020

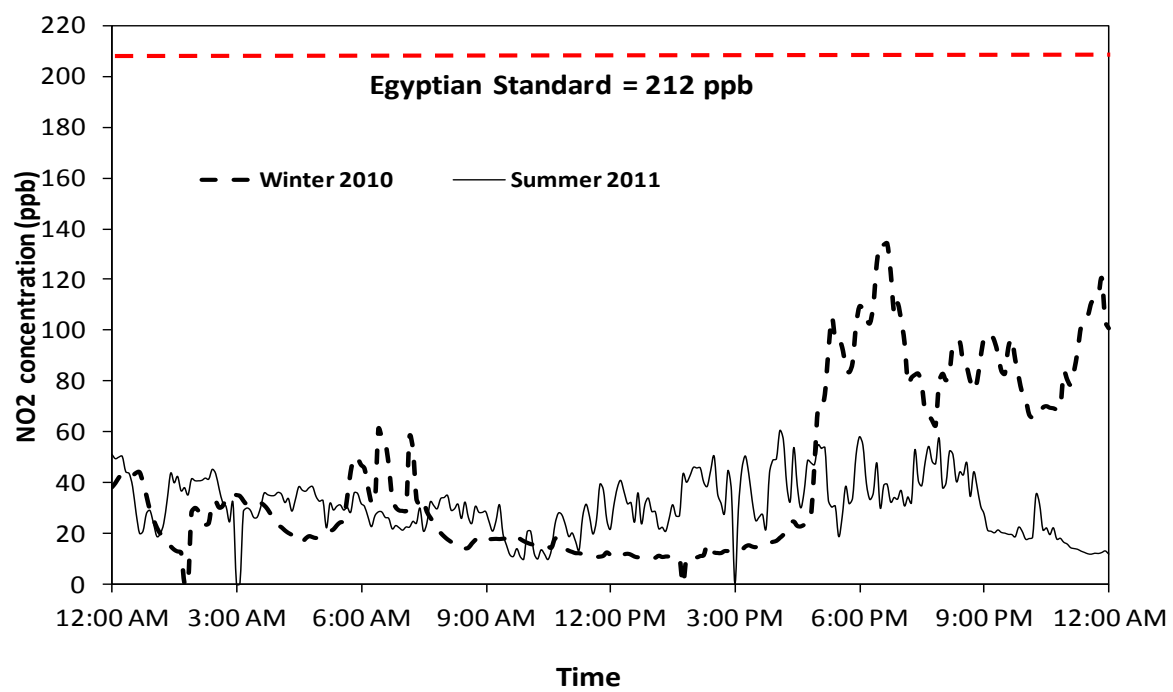

(c)

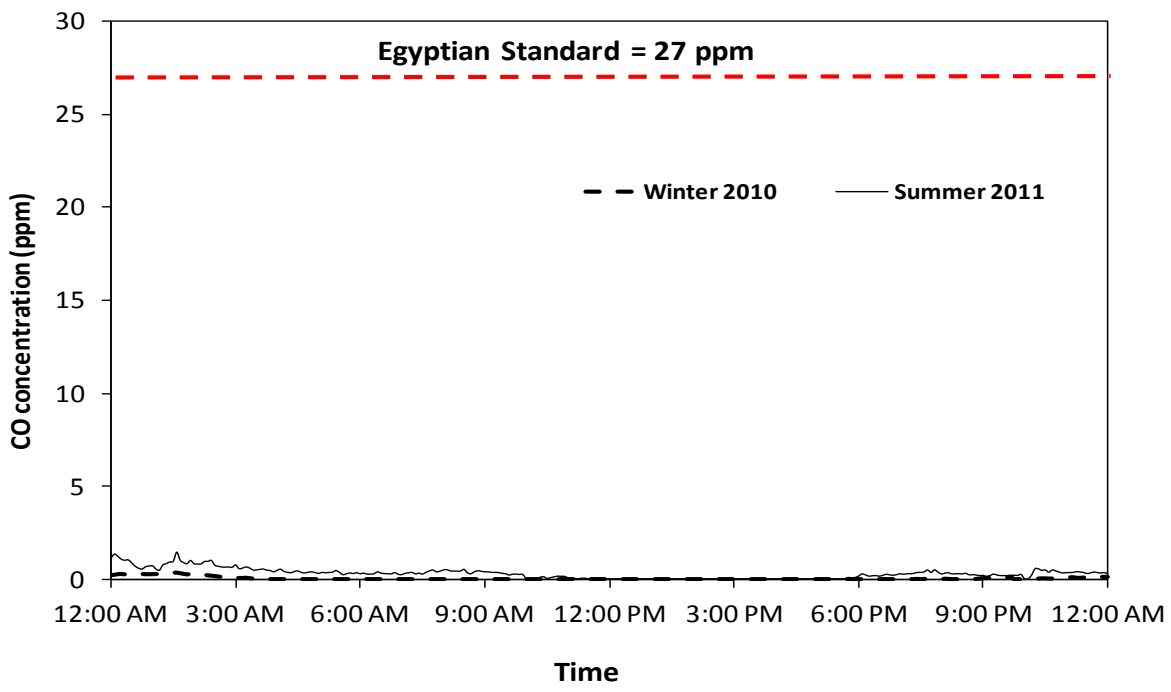

(d)

Journal of Engineering Sciences, Assiut University, Faculty of Engineering, Vol. 41, No. 3, May, 2013,E-mail address: jes@aun.edu.eg 
M. Bady, Assessment of urban air quality in Assiut city-Egypt based on full scale measurements of air pollutants, pp. $997-1020$

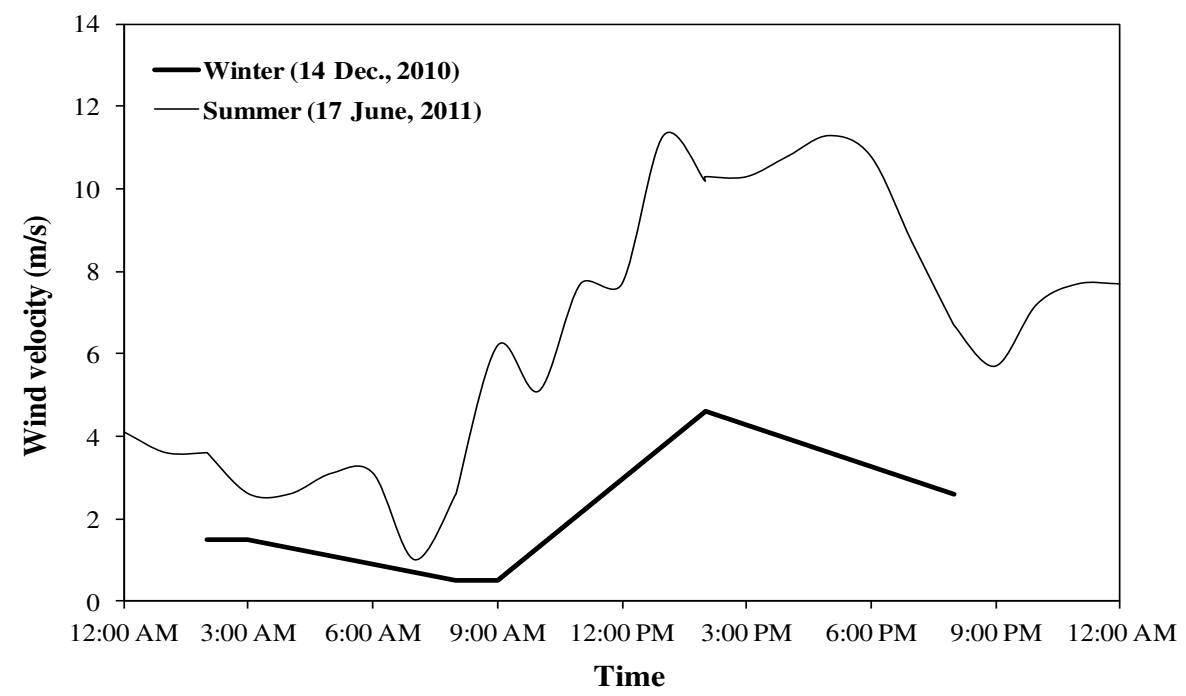

(e)

Fig. 8. The measured wind velocity and pollutant concentration in Nazlet Abdellah site.

Although, the $\mathrm{PM}_{10}$ concentration in winter is very low along the day, the measurement clearly shows that; it is very high in summer. At some times along the day, the concentration was ranging from 60 to $308 \mu \mathrm{g} / \mathrm{m}^{3}$ with an average value of $175 \mu \mathrm{g} / \mathrm{m}^{3}$. Such concentration level is greater than the permitted daily average value of $150 \mu \mathrm{g} / \mathrm{m}^{3}$ stipulated in the Egyptian standard and the EPA standard.

The $\mathrm{SO}_{2}$ concentration is almost constant during the measurement period in winter. In summer, it is almost constant along the first half of the day, while it is fluctuating during the second half. In summer, the $\mathrm{SO}_{2}$ concentration is very high compared to the other three sites. During the time from 12:00 PM to 10:00 PM, the $\mathrm{SO}_{2}$ concentration average value is $80 \mu \mathrm{g} / \mathrm{m}^{3}$. This value exceeds the Egyptian standard annual limit by approximately $33 \%$. This higher value is attributed to that; the location of this site is downwind of the thermal power plant of Assiut city.

The concentrations of $\mathrm{NO}_{2}$ show high fluctuations with time, it exceeds the Egyptian standard in the evening period in winter. The emissions from Assiut thermal power plant together with the vehicular emissions of $\mathrm{NO}_{2}$ (diesel engine vehicles) represent the main source of $\mathrm{NO}_{2}$ in this site.

It can be seen clearly from Fig. 8 that, the measured levels of $\mathrm{CO}$ are very low compared with the standard limit along the $24 \mathrm{hrs}$ in both winter and summer seasons. This can be attributed to the limited number of vehicles fuelled with gasoline that pass through the traffic road near this site compared to the diesel fuelled vehicles. 
M. Bady, Assessment of urban air quality in Assiut city-Egypt based on full scale measurements of air pollutants, pp. $997-1020$

\section{Table 4.}

The determined AQI for each pollutant in winter and summer seasons in the four sites

\begin{tabular}{lcccccccc}
\hline \multicolumn{1}{c}{ Site } & \multicolumn{2}{c}{ PM $_{\mathbf{1 0}}$} & \multicolumn{2}{c}{ SO $_{\mathbf{2}}$} & \multicolumn{2}{c}{ NO $_{\mathbf{2}}$} & \multicolumn{2}{c}{ CO } \\
& Summer & Winter & Summer & Winter & Summer & Winter & Summer & Winter \\
\hline 1. El-Arbein & 1225 & 368 & 11 & 32 & 71 & 31 & 33 & 23 \\
2. Univ. old-campus & 304 & 0 & 28 & 46 & 28 & 25 & 19 & 16 \\
3. Nazlet Abdellah & 1236 & 479 & 394 & 34 & 104 & 140 & 14 & 2 \\
4. Assiut Hospital & 1142 & 351 & 24 & 23 & 53 & 131 & 43 & 8 \\
\hline \hline
\end{tabular}

It is obvious from these results that the $\mathrm{PM}_{10}$ is the common pollutant in the four considered sites within Assiut city, and that dust is found in both summer and winter seasons and commonly exceeds the daily allowable limit at different times during the day. Such result reflects a part of the dust problem in Egypt as a whole. High levels of $\mathrm{NO}_{2}$ concentrations in Assiut are found in two sites, while those of $\mathrm{SO}_{2}$ are found in one site. Finally, the $\mathrm{CO}$ levels in all sites are acceptable and do not represent a problem in both winter and summer seasons.

\subsection{Assessment of Air Quality based on the Total AQI}

The calculated values of total AQI are presented in Table 5 and presented graphically in Fig. 9 for the four measurement sites in the two seasons. Table 5 shows also, the air quality category which corresponds to the estimated AQI in all sites in both the summer and winter seasons.

\section{Table 5.}

The determined AQI for the four measurement sites

\begin{tabular}{lcccc}
\hline & \multicolumn{2}{c}{ Summer 2011 } & \multicolumn{2}{c}{ Winter 2010 } \\
\hline \multicolumn{1}{c}{ No Site } & AQI & $\begin{array}{c}\text { Description of } \\
\text { air quality } \\
\text { category }\end{array}$ & AQI & $\begin{array}{c}\text { Description of } \\
\text { air quality } \\
\text { category }\end{array}$ \\
\hline 1. El-Arbein & $1225\left(\mathrm{PM}_{10}\right)$ & Hazardous & $368\left(\mathrm{PM}_{10}\right)$ & Hazardous \\
2. University old-campus & $1236\left(\mathrm{PM}_{10}\right)$ & Hazardous & $140\left(\mathrm{NO}_{2}\right)$ & Unhealthful \\
3. Nazlet Abdellah & $304\left(\mathrm{PM}_{10}\right)$ & Hazardous & $479\left(\mathrm{PM}_{10}\right)$ & Hazardous \\
4. Assiut Hospital & $1142\left(\mathrm{PM}_{10}\right)$ & Hazardous & $351\left(\mathrm{PM}_{10}\right)$ & Hazardous \\
\hline
\end{tabular}

It can be seen clearly from the presented values of total AQI that; the air quality in the selected sites in Assiut city is pessimistic, particularly as far as particulate matters $\left(\mathrm{PM}_{10}\right)$ are concerned. In summer, the AQI value exceeds the limit of 500 for three of the measurement sites. The determined values of the total AQI are about 2.5 times the extreme limit of 500 in almost all sites. The pollutant that makes the worst air quality condition hazardous in the four sites is the suspended particulate matter; that is $\mathrm{PM}_{10}$. In winter, the AQI values are under 500 in all sites. However, the AQI values are located within the hazardous conditions (E), except for the site in the University old campus which is 
1018

M. Bady, Assessment of urban air quality in Assiut city-Egypt based on full scale measurements of air pollutants, pp. 997 - 1020

unhealthful. Accordingly, it can be stated that; in both winter and summer, $\mathrm{PM}_{10}$ is the worst parameter among all calculated AQIs. Such result reflects the problem of dust that Egypt suffers from.
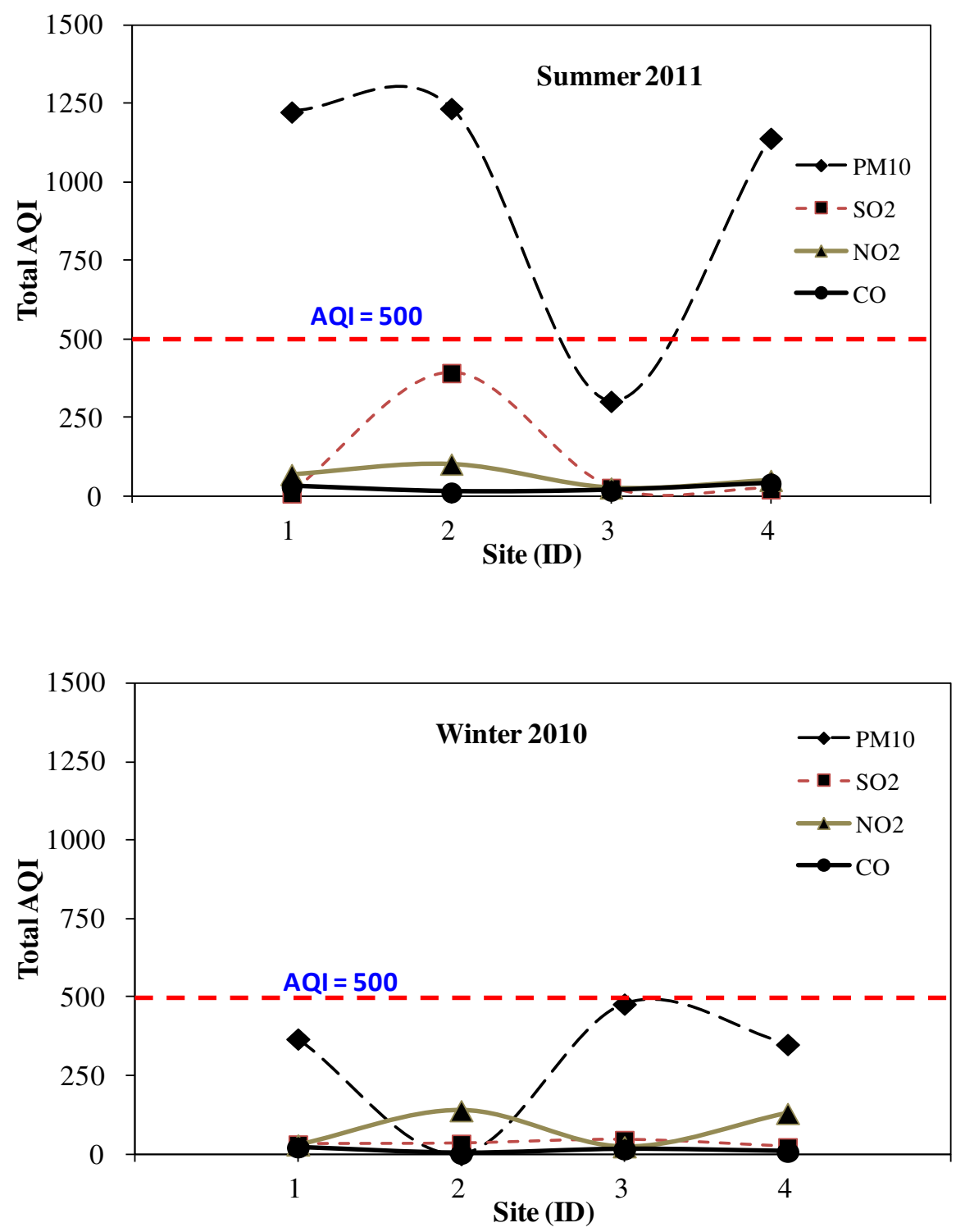

Fig. 9. Comparison between the total AQI in the four sites; in summer 2011 (left), and in winter 2010 (right).

Journal of Engineering Sciences, Assiut University, Faculty of Engineering, Vol. 41, No. 3, May, 2013,E-mail address: jes@aun.edu.eg 
M. Bady, Assessment of urban air quality in Assiut city-Egypt based on full scale measurements of air pollutants, pp. $997-1020$

\section{Conclusions}

An assessment of the air quality in Assiut city, Egypt; has been clarified throughout measurements of concentrations of major air pollutants, which are $\mathrm{SO}_{2}, \mathrm{NO}_{2}, \mathrm{PM}_{10}$ and $\mathrm{CO}$. Full-scale measurements of these pollutants daily concentrations variations in summer and in winter seasons at four selected sites in Assiut city, Egypt were carried out using a mobile monitoring unit. The air quality analysis was performed by determining the Air Quality Index (AQI) based on the four considered pollutants. The maximum daily and annual values from the Egyptian air quality standards for each pollutant are considered in the present assessment. The study results show that:

1- The air pollution levels in Assiut city reached very high concentrations due to a combination of emission from a number of different sources and adverse weather conditions.

2- The measured concentrations in the four sites showed that; the $\mathrm{SO}_{2}$ concentrations may exceed AQI levels in urban areas and close to industrial sources. The levels of $\mathrm{NO}_{2}$ seldom exceeded the AQI levels. The CO levels in the four sites are very low when compared with the standard value of $9 \mathrm{ppm}$.

3- The recorded concentrations of $\mathrm{PM}_{10}$ are the corner stone as the major source of pollution. It is the main factor in the hazardous air quality conditions in Assiut city.

4- The determined AQI value exceeded the standard value of 500 in summer. It is about 2.5 times the extreme limit of 500 in almost all sites. In winter, the AQI values are below 500 in all measurement sites. However, in both seasons, the AQI values reflect hazardous air quality conditions in almost all measurement sites.

5- The findings of the research help in taking decisions concerning the design of new build-up area in Assiut. Designers have to take in their considerations, the effect of transportation system within the new areas on the air quality.

\section{References}

[1] Egypt State of the Environment, Air Quality Report, (2010).

[2] Inhaber H., (1976), Environmental Indices. Wiley, New York.

[3] Biswanath B., Amit P., and Jain V., (2009), A Comparative Study of Air Quality Index Based on Factor Analysis and US-EPA Methods for an Urban Environment, Aerosol and Air Quality Research, Vol. 9(1), 1-17.

[4] Rossbach M., Jayasekera R., Kniewald G., and Thang N., (1999), Large scale air monitoring: lichen vs. air particulate matter analysis. The Science of the Total Environment 232, 59-66.

[5] Guleda O., Ibrahim D., and Halil H. (2004), Assessment of urban air quality in Istanbul using fuzzy synthetic evaluation, Atmospheric Environment, 38, 3809-3815.

[6] Fisher, B., 2003. Fuzzy Environmental Decision-making: Applications to Air pollution. Atmospheric Environment 37, 1865-1877.

[7] EPA-US Environmental Protection Agency, (2000). A Guide to Air Quality and Your Health, Air Quality Index, EPA-454/R-00-005, USA.

[8] http://www.environnement-sa.com/

Journal of Engineering Sciences, Assiut University, Faculty of Engineering, Vol. 41, No. 3, May, 2013, E-mail address: jes@aun.edu.eg 
M. Bady, Assessment of urban air quality in Assiut city-Egypt based on full scale measurements of air pollutants, pp. $997-1020$

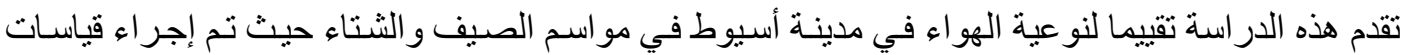

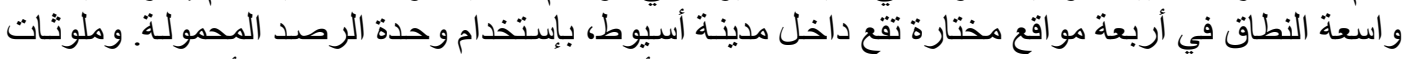

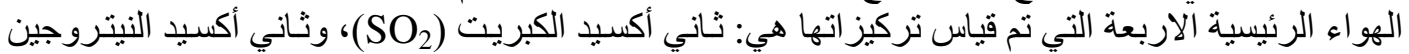

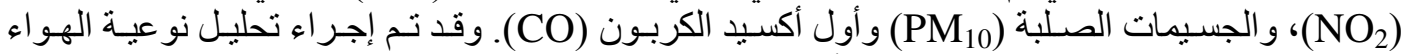

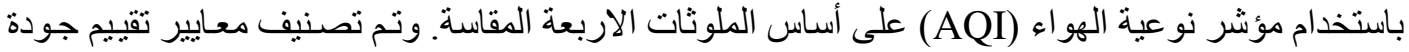

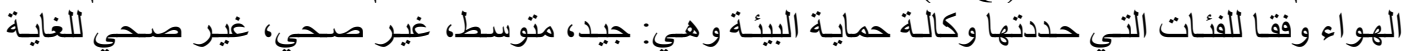

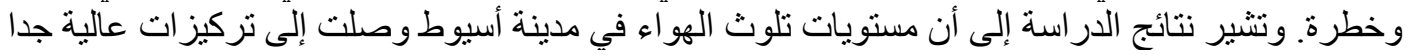

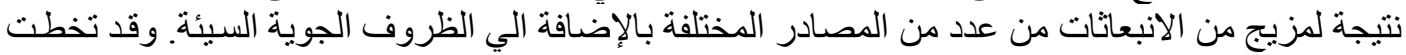

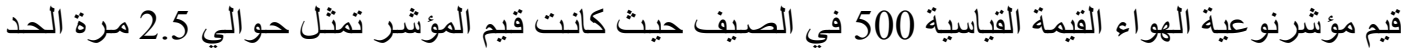

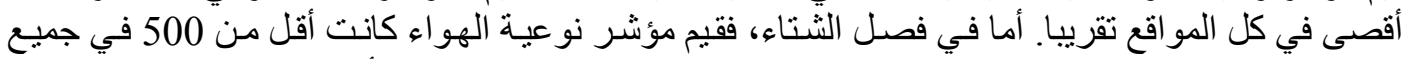

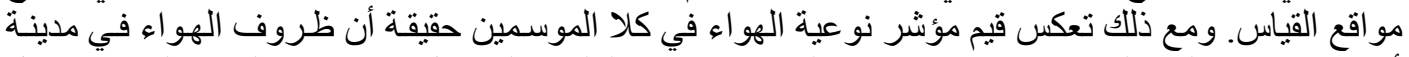

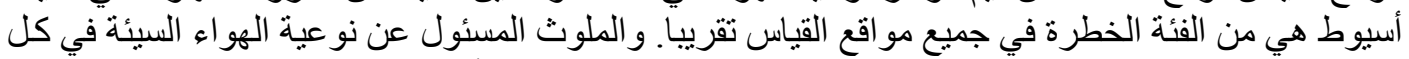

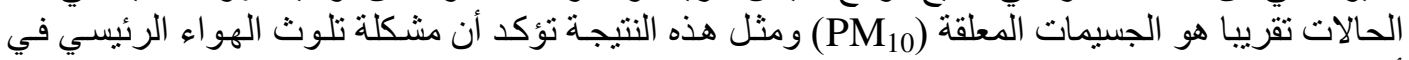
أسيوط هو الغبار. تهريا هو

Journal of Engineering Sciences, Assiut University, Faculty of Engineering, Vol. 41, No. 3, May, 2013,E-mail address: jes@aun.edu.eg 